\title{
Estudo de diferentes combinações de melaço/ vinhaça como substrato para produção de proteínas e lipídios por microrganismos
}

\section{Study of molasses / vinasse waste ratio for single cell protein and total lipids production by}

\author{
Marcia Luciana Cazetta ${ }^{1}$; Maria Antonia P. C. Celligoi ${ }^{2}$
}

\section{Resumo}

Diferentes combinações de melaço e vinhaça de cana-de-açúcar foram utilizadas como substrato para produção de biomassa protéica e lipídica por cinco microrganismos: quatro linhagens de leveduras: Candida lipolytica, Rhodotorula mucilaginosa, Saccharomyces cerevisiae, uma levedura isolada das lagoas de vinhaça (denominada LLV98) e uma bactéria, Corynebacterium glutamicum. Os meios utilizados foram: a) $50 \%$ de melaço e $50 \%$ de vinhaça; b) $25 \%$ de melaço e $75 \%$ de vinhaça e c) $75 \%$ de melaço e $25 \%$ de vinhaça. O objetivo deste trabalho foi estudar o crescimento celular e a produção de proteínas e lipídios na biomassa obtida a partir desses subprodutos. A maior produção de proteína na biomassa foi obtida por S. cerevisiae, 50,35\%, seguida por $R$. mucilaginosa, $41,96 \%$, em $25 \%$ de melaço e $75 \%$ de vinhaça. As menores produções de proteína foram obtidas por $C$. glutamicum. A melhor produção de lipídios totais, acima de $26 \%$, foi obtida no meio de $50 \%$ de melaço e $50 \%$ de vinhaça por S. cerevisiae e C. glutamicum.

Palavras-chave: Vinhaça.Melaço. Biomassa. Proteína. Lipídios. Microrganismos.

\begin{abstract}
Different molasses/ vinasse ratio were used as substrate to investigate single cell protein and total lipids production by five microorganisms: four yeasts strains: Candida lipolytica, Rhodotorula mucilaginosa, Saccharomyces cerevisiae, a yeast isolated from vinasse lake (denominated LLV98) and a bacterium strain, Corynebacterium glutamicum. The media utilized were: a) 50\% molasses and 50\% vinasse; b) $25 \%$ molasses and $75 \%$ vinasse and c) $75 \%$ molasses and $25 \%$ vinasse. The objective of this work was to study the growth of microorganisms and also evaluate protein and lipids content in the biomass obtained from these by-products. The highest single cell protein production was obtained by $S$. cerevisiae, $50.35 \%$, followed by $R$. mucilaginosa, $41.96 \%$. The lowest productions were obtained by C. glutamicum. The higher total lipids productions, more than $26 \%$, were founded in molasses plus vinasse at $50 \% 150 \%$ by $S$. cerevisiae and C. glutamicum.
\end{abstract}

Key words: Vinasse. Molasses. Single cell protein. Total lipids. Microorganisms

\footnotetext{
${ }^{1}$ Doutora em Ciências Biológicas - Área de concentração em Microbiologia Aplicada. Itápolis-SP.- Email: malulz@yahoo.com.br

2 Docente do Departamento de Bioquímica e Biotecnologia - Universidade Estadual de Londrina.
} 


\section{Introduction}

Interest in industrial wastes as substrate for single cell protein production has increased recently (EMTIAZI; ETEMADIFAR; TAVASSOLI, 2003) for application as protein sources of high nutrition value and for environmental pollution control (NAVARRO; SEPÚLVEDA; RUBIO, 2000; PARASKEVOPOULOU et al., 2003). Many byproducts or wastes, such as cheese whey (PARASKEVOUPOLOU et al., 2003), wastewater from glutamate fermentation (ZHENG et al., 2005) and cellulosic material are abundant in several countries and can be used as raw material for developing biotechnological process of industrial interest (ALTAF et al., 2005) by many microorganisms as yeasts, bacteria, algae and fungi (ARNOLD; KNAPP; JONHSON, 2000; ANUPAMA; RAVINDRA, 2000).

Furthermore, the interest for new sources of essential fatty acids has increased. Recently, the attention for yeasts and other microorganisms which are called oleaginous or "oil bearing", has been renewed, as source of oils and fats (RUPCIC; BLAGOVIC; MARIC, 1996; DYAL; NARINE, 2005).

Molasses is an agro-industrial by-product often used in alcohol distilleries due to the presence of fermentative sugars, being a good carbon source for the microorganism metabolism. Sugar cane molasses and vinasse are an abundant agro-industrial material produced in Brazil and other tropical countries and their low cost is an important factor for the economical viability of substances produced by fermentation. Its composition is rich in organic salts like nitrogen, phosphates, calcium and magnesium as well as micronutrients as zinc, manganese, copper and iron, besides many amino acids (WALISZEWSKI; ROMERO; PARDIO, 1997; CORTÉZ; BROSSARD-PÉREZ, 1997).
The vinasse is the major effluent from the ethanol industry and represents a major environmental problem. This black liquid is produced at a rate of 10 to 15 liters for each ethanol liter and it is a mixture of water and organic and inorganic compounds (MENEZES, 1980; ANCIÃES, 1981; POLACK; DAY; CHO, 1981).

In Brazil, most of the vinasse that results from ethanol production is being used as fertilizer due to its organic matter content and nutrients like high potassium and nitrogen contents $\left(30 \mathrm{~g} \mathrm{Kg}^{-}\right.$ ${ }^{1}$ dry weight) Diaz et al. (2003). The problem occurs when some soils do not respond positively to the application of this acid material (WARD, 1991; CORTEZ; BROSSARD PEREZ, 1997) reducing the alkalinity of the soil, destroying the crops (KUMAR; VISWANATHAN, 1991), causing manganese deficiency in the soil (AGRAWAL; PANDEY, 1994) and inhibiting seed germination (KANNABIAN; PRAGASAN, 1993).

In this work, our objective was to study the growth of microorganisms in a mixture of molasses and vinasse and also evaluate protein and lipid content in the biomass obtained from these by-products.

\section{Material and Methods}

Microorganisms: Microorganisms utilized were Candida lipolytica, Rhodotorula mucilaginosa, Saccharomyces cerevisiae, a yeast isolated from vinasse lake (denominated LLV98) and bacterium Corynebacterium glutamicum.

Fermentation medium: For fermentation medium sugar cane molasses and vinasse were utilized with different rates: a) $50 \%$ molasses and $50 \%$ vinasse, b) $25 \%$ molasses and $75 \%$ vinasse and c) $75 \%$ molasses and $25 \%$ vinasse. Molasses and vinasse were obtained from Cooperativa Agrícola de Rolândia - COROL - Paraná, Brazil. 
Fermentations: Fermentations were carried out in $250 \mathrm{~mL}$ Erlenmeyer flasks containing $50 \mathrm{~mL}$ fermentation medium, in duplicate, at $28^{\circ} \mathrm{C} \pm 2^{\circ} \mathrm{C}$ and agitation rate of $180 \mathrm{rpm}$.

Analytical methods: The single cell protein was assayed for its moisture content by drying of the sample at $105^{\circ} \mathrm{C}$ until constant weight and against standard curve of dry mass $x$ optic density. Its protein content was determined by applying the Kjeldahl method ( $\mathrm{N} \times 6.25)$ (ASSOCIATION OF OFFICIAL ANALYTICAL CHEMISTS, 1984).

Determination of reducing sugars: The reducing sugars from cultures were firstly hydrolyzed by $\mathrm{HCl} 2 \mathrm{M}$ and boiled during 5 minutes. After that, the solution was neutralized with $\mathrm{NaOH} 2 \mathrm{M}$. Reducing sugars were determined by Somogy (1945) and Nelson (1944) method.

Determination of total lipids: Lipids were extracted with a mixture of chloroform-methanol $(1: 1, v / v)$ according to ASSOCIATION OF OFFICIAL ANALYTICAL CHEMISTS method (1975). The total lipids content in the extract was quantified by Frings e Dunn's method (1971).

\section{Results and Discussion}

a) Fermentation in 50\% molasses and 50\% vinasse

This culture condition was unfavorable for biomass production by both yeast LLV98 and $C$. glutamicum, achieving concentrations lower than $1.00 \mathrm{~g} / \mathrm{L}$. Rhodotorula mucilaginosa also showed low biomass production, $2.63 \mathrm{~g} / \mathrm{L}$. Highest biomass were obtained by both $S$. cerevisiae and C. lipolytica, $7.49 \mathrm{~g} / \mathrm{L}$ and $6.90 \mathrm{~g} /$ $\mathrm{L}$, respectively. Saccharomyces cerevisiae obtained highest biomass protein yield, $2.55 \mathrm{~g} / \mathrm{L}$ and highest productivity, $0.15 \mathrm{~g} / \mathrm{L} \cdot \mathrm{h}^{-1}$ (figure 1). Sugar consumption was low for all microorganisms, except for $S$. cerevisiae, which consumed $98.25 \%$ (Table 1 and figure 2).

The total lipid content analysis showed that molasses and vinasses at 50\%/ 50\% stimulated lipid production by both $S$. cerevisiae and $C$. glutamicum, which obtained more than $26 \%$. Lipid values obtained by both $S$. cerevisiae and $C$. glutamicum in this culture condition are close to described for oleaginous microorganisms. As described by Murphy (1991) and Ratledge (1996), yeasts and fungi that contain more than

Table 1 - Biomass yield (g/L), total lipid yield (\%) and substrate consumption (\%) in molasses 50\% and vinasse $50 \%$ after 48 hours.

\begin{tabular}{lccc}
\hline \multicolumn{1}{c}{ Microorganism } & Biomass & $\begin{array}{c}\text { Substrate } \\
\text { consumption }\end{array}$ & Total lipids \\
& $(\mathrm{g} / \mathrm{L})$ & $(\%)$ & $(\%)$ \\
\hline Candida lipolytica & $\mathbf{6 . 9 0}$ & $\mathbf{3 0 . 0 5}$ & 17.68 \\
Yea st LLV98 & $\mathbf{0 . 4 1}$ & 14.50 & 8.98 \\
Rhodotorula mucilaginosa & 2.63 & 37.48 & 19.50 \\
Saccharomyces cerevisiae & 7.49 & $\mathbf{9 8 . 2 5}$ & $\mathbf{2 6 . 9 0}$ \\
Corynebacterium glutamicum & $\mathbf{0 . 5 1}$ & 14.02 & $\mathbf{2 6 . 5 0}$ \\
\hline
\end{tabular}




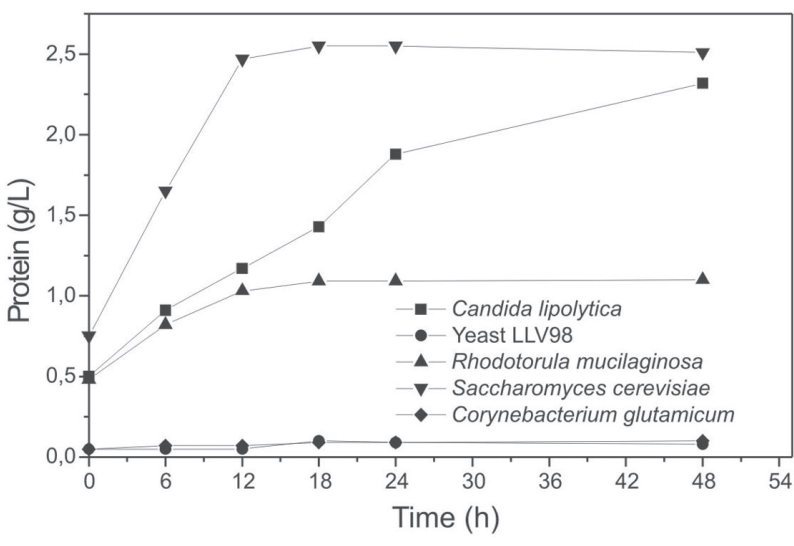

Figure 1. Protein production $(\mathrm{g} / \mathrm{L})$ in $50 \%$ molasses and $50 \%$ vinasse after 48 hours.

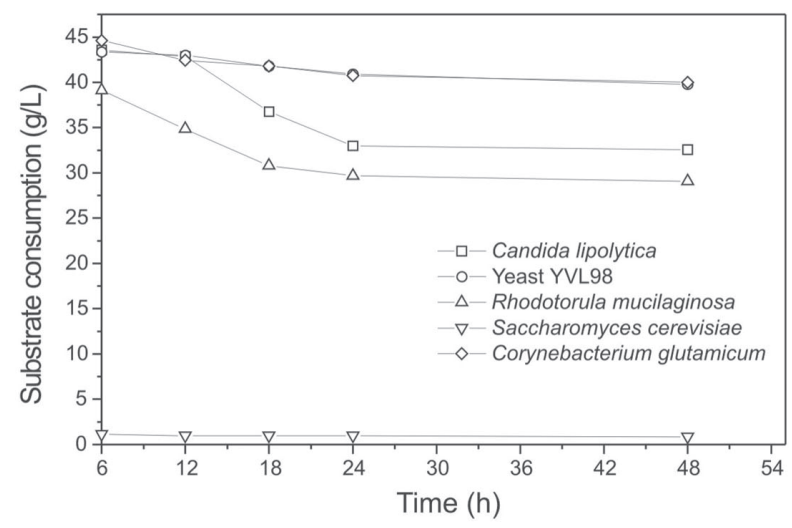

Figure 2. Substrate consumption $(\mathrm{g} / \mathrm{L})$ in $50 \%$ molasses and $50 \%$ vinasse after 48 hours.

$25 \%$ of their biomass in the form of lipids are defined as oleaginous microorganisms. These results were higher than those obtained using molasses and vinasse separately (unpublished results).

The values reached by both $R$. mucilaginosa and C. lipolytica varied from 17 to $19.5 \%$, which are higher than those obtained by Rupcic, Blagovic and Maric (1996), who produced $14 \%$ of lipids in glucose at $1 \%$. Yeast LLV98 obtained $8.9 \%$. Saccharomyces cerevisiae showed best total lipid yield and productivity, $2.0 \mathrm{~g} / \mathrm{L}$ and $0.12 \mathrm{~g} / \mathrm{L}^{-\mathrm{h}^{-1}}$, respectively (Figure 3).

\section{c) Fermentation in molasses $75 \%$ and vinasse $25 \%$}

.yeast LLV98 and $R$. mucilaginosa produced about $5.0 \mathrm{~g} / \mathrm{L}$ while C. lipolytica achieved $4.14 \mathrm{~g} / \mathrm{L}$ and C. glutamicum $2.78 \mathrm{~g} / \mathrm{L}$. The highest protein yield was obtained by $S$. cerevisiae $(2.52 \mathrm{~g} / \mathrm{L})$ followed by $R$. mucilaginosa $(1.80 \mathrm{~g} / \mathrm{L})$, while $C$. lipolytica

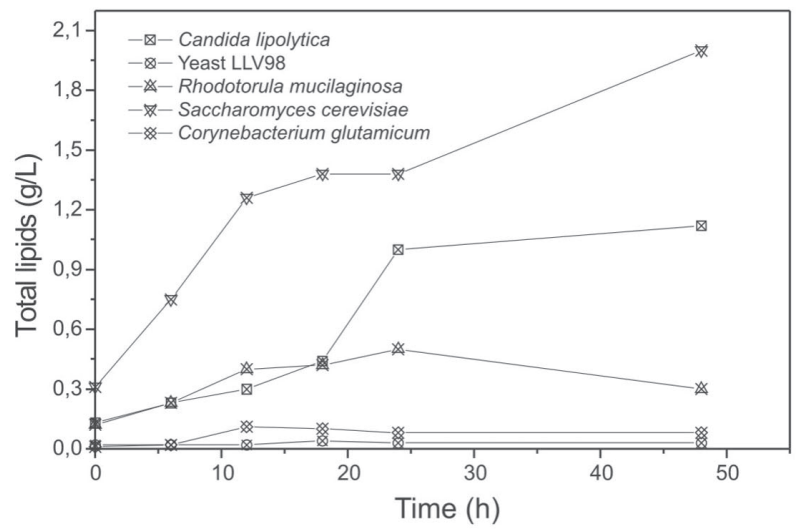

Figure 3. Lipid productions (g/L) in molasses $50 \%$ and vinasse $50 \%$ after 48 hours

b) Fermentation in 25\% molasses and $75 \%$ vinasse

Biomass production in $25 \%$ molasses and $75 \%$ vinasse ranged from 4.0 to $7.0 \mathrm{~g} / \mathrm{L}$. Corynebacterium glutamicum, $R$. mucilaginosa and yeast LLV98 reached higher biomass production than in the previous experiment. Candida lipolytica showed similar biomass production than in molasses and vinasse 50\%/ $50 \%$; for S. cerevisiae the biomass production decreased $22.3 \%$.

Highest protein production was obtained by $R$. mucilaginosa, $2.54 \mathrm{~g} / \mathrm{L}$ (Figure 4) but the highest productivity was reached by $S$. cerevisiae, $0.22 \mathrm{~g} /$ L. $h^{-1}$. This protein productivity was the same as the one found in the experiments of Rueger and TaukTornizielo (1996), $0.202 \mathrm{~g} / \mathrm{L}^{1}$, in mixed culture of Aspergillus niger and Penicillium fellutanum in vinasse plus molasses at $50 \mathrm{~g} / \mathrm{L}$. Crude protein content was $50 \%$ of the $S$. cerevisiae dry weight, which was similar to values described by Kefir 
microflora $(54 \%)$ in cheese whey (PARASKEVOPOULOU et al., 2003). Saccharomyces cerevisiae is classified among the most interesting microorganisms for their protein content, which can account $50 \%$ of the dry weight (ZIINO et al., 1999). Rhodotorula mucilaginosa achieved $41.96 \%$ of biomass protein percentage, while $C$. lipolytica and yeast LLV98 was about $33.5 \%$ and C. glutamicum, $25.18 \%$.

Substrate consumption was higher than previous assays, except to $S$. cerevisiae that shown slight decrease (from 98\% to 90\%) (Table 2 and Figure 5).

Table 2.

Biomass yield (g/L), total lipid yield (\%) and substrate consumption (\%) in molasses $25 \%$ and vinasse $75 \%$ after 48 hours.

\begin{tabular}{lccc}
\hline Microorganisms & $\begin{array}{c}\text { Biomass } \\
(\mathrm{g} / \mathrm{L})\end{array}$ & $\begin{array}{c}\text { Substrate } \\
\text { consumption(\%) }\end{array}$ & $\begin{array}{c}\text { Total lipids } \\
(\%)\end{array}$ \\
\hline Candida lipolytica & 7.00 & 93.50 & 8.92 \\
Yeast LLV98 & 6.88 & 94.93 & 10.64 \\
Rhodotorula mucilaginosa & 7.56 & 73.93 & 10.32 \\
Saccharomyces cerevisiae & 5.82 & 90.48 & 8.83 \\
Corynebacterium glutamicum & 4.20 & 18.95 & 14.40 \\
\hline
\end{tabular}

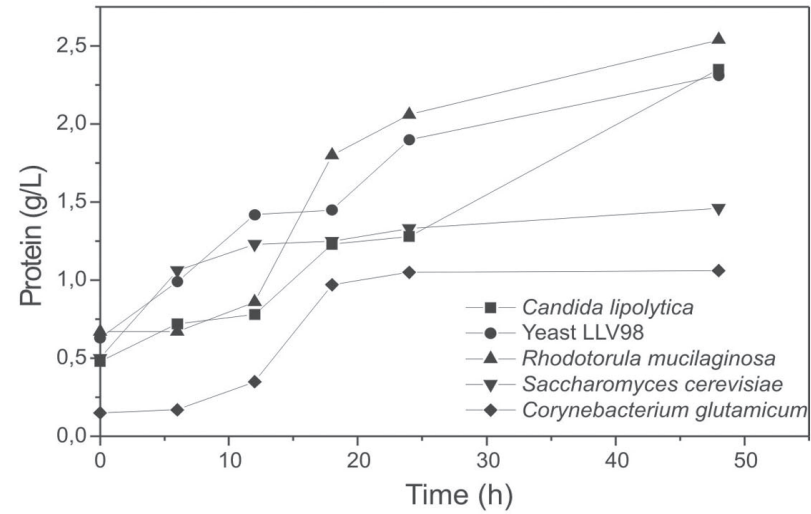

Figure 4. Protein productin $(\mathrm{g} / \mathrm{L})$ in $25 \%$ molasses and $75 \%$ vinasse after 48 hours.

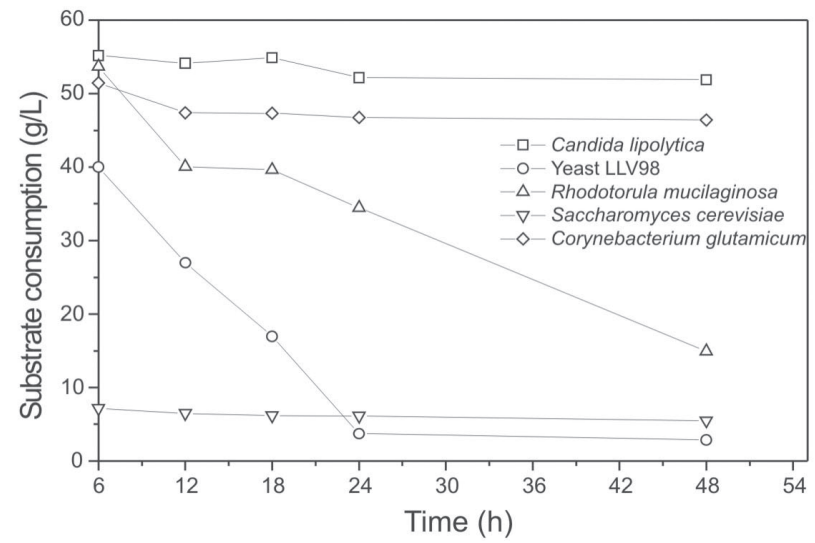

Figure 5. Substrate consumption $(\mathrm{g} / \mathrm{L})$ in $25 \%$ molasses and $75 \%$ vinasse after 48 hours.
The total lipid production by $C$. glutamicum was $14,4 \%$; both $R$. mucilaginosa and yeast LLV98 produced about $10 \%$, while $C$. lipolytica and $S$. cerevisiae achieved little more than $8 \%$. This lipid content was lower than that obtained in molasses plus vinasse at 50\%-50\%, except to yeast LLV98 that obtained slight higher values. It seems that this vinasse concentration caused a decrease in the lipid synthesis, so that its availability for biomass production increased. The decrease in lipid synthesis did not occur for yeast LLV98 because it was already adapted to the vinasse.

The highest lipids yields, $0.78 \mathrm{~g} / \mathrm{L}$ and $0.73 \mathrm{~g} / \mathrm{L}$, in such culture condition, were obtained by $R$. mucilaginosa and yeast LLV98, respectively. Candida lipolytica and $C$. glutamicum produced $0.50 \mathrm{~g} / \mathrm{L}$ while $S$. cerevisiae, $0.34 \mathrm{~g} / \mathrm{L}$ (Fig. 6). 


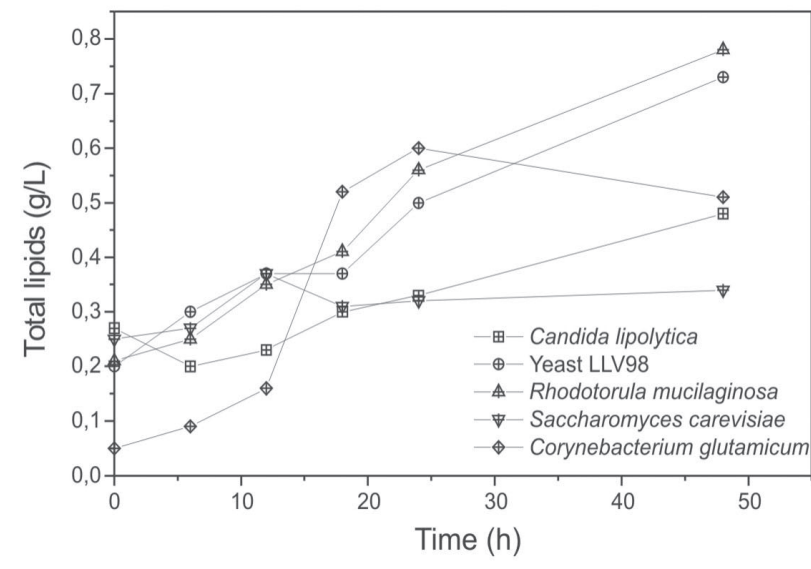

Figure 6. Total lipid production $(\mathrm{g} / \mathrm{L})$ in $25 \%$ molasses and $75 \%$ vinasse after 48 hours.

and yeast LLV98 produced about $1.65 \mathrm{~g} / \mathrm{L}$ and $C$. glutamicum only $0.50 \mathrm{~g} / \mathrm{L}$.

The sugar consumption was high only to $S$. cerevisiae and yeast LLV98 (more than $80 \%$ ); on the other hand, it was low to $C$. lipolytica (about $30 \%$ ), reaching approximately $10 \%$ to both $R$. mucilaginosa and C. glutamicum (Figure 8).

Total lipids contents ranged from 10.69 to $19.62 \%$. These values were slightly lower than those obtained in 50\% molasses and 50\% vinasse. On the other hand, these values were higher than those obtained in experiments using $25 \%$ molasses and $75 \%$ vinasse by $C$. lipolytica, $R$. mucilaginosa, $S$. cerevisiae and $C$. glutamicum. The highest total lipid contents, $0.86 \mathrm{~g} / \mathrm{L}$ and 0.76

Table 3 - Biomass yield (g/L), total lipid yield (\%) and substrate consumption (\%) in molasses $75 \%$ and vinasse $25 \%$ after 48 hours.

\begin{tabular}{lccc}
\hline Microorganisms & $\begin{array}{c}\text { Biomass } \\
(\mathrm{g} / \mathrm{L})\end{array}$ & $\begin{array}{c}\text { Substrate } \\
\text { consumption(\%) }\end{array}$ & $\begin{array}{c}\text { Total lipids } \\
(\%)\end{array}$ \\
\hline Candida lipolytica & 4.14 & 30.53 & 12.48 \\
Yeast LLV98 & 4.96 & 81.40 & 10.86 \\
Rhodotorula mucilaginosa & 5.34 & 10.16 & 14.25 \\
Saccharomyces cerevisiae & 7.20 & 95.09 & 12.48 \\
Corynebacterium glutamicum & 2.78 & 11.00 & 19.68 \\
\hline
\end{tabular}

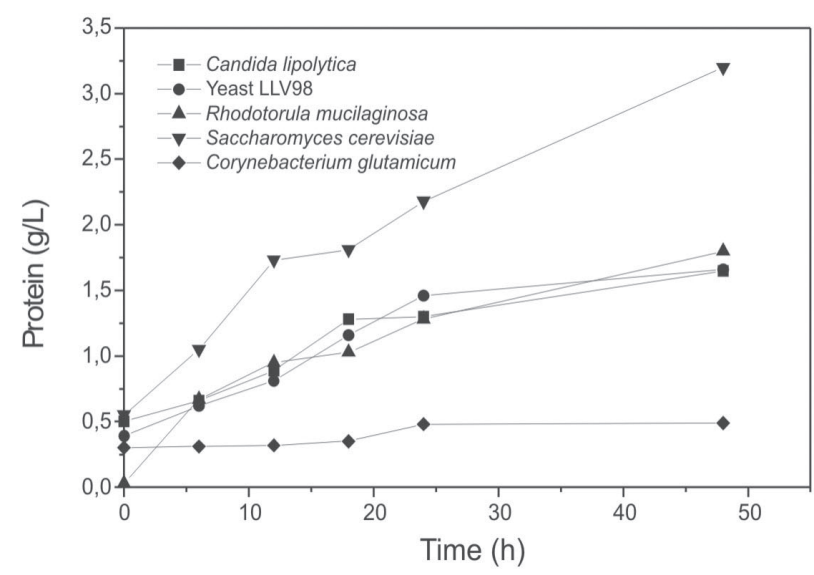

Figure 7. Protein production $(\mathrm{g} / \mathrm{L})$ in $75 \%$ molasses and $25 \%$ vinasse after 48 hours.

When comparing the protein productions, one can observe that $S$. cerevisiae showed the best results in this matter. On the other hand, $C$. glutamicum showed the lowest protein production in all culture media. In general, the yeast LLV98 did not reach satisfactory results, except at $25 \%$ molasses and $75 \%$ vinasse where this microorganism showed a protein production only lower than S. cerevisiae.

Regarding the lipid production percentages, the culture medium using 50\% molasses and $50 \%$ vinasse was the best condition for all microorganisms, except yeast LLV98 that was not influenced by culture mediums showing

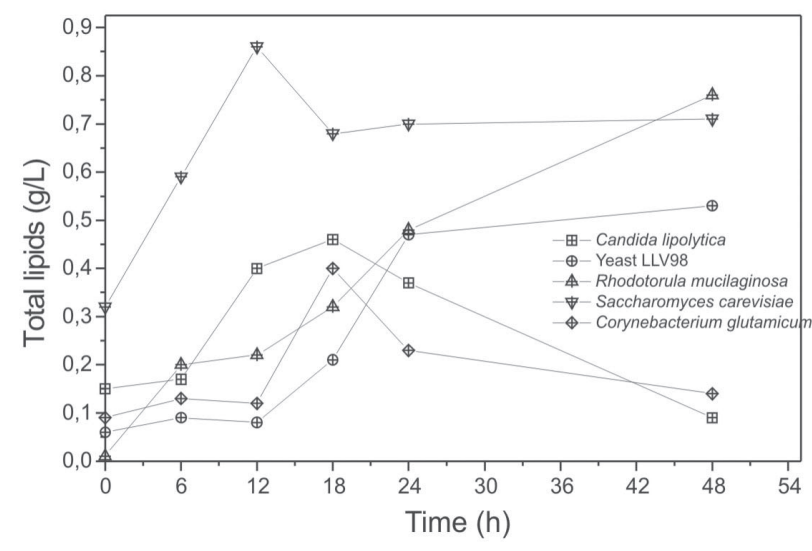

Figure 8. Substrate consumption $(\mathrm{g} / \mathrm{L})$ in $75 \%$ molasses and $25 \%$ vinasse after 48 hours. 


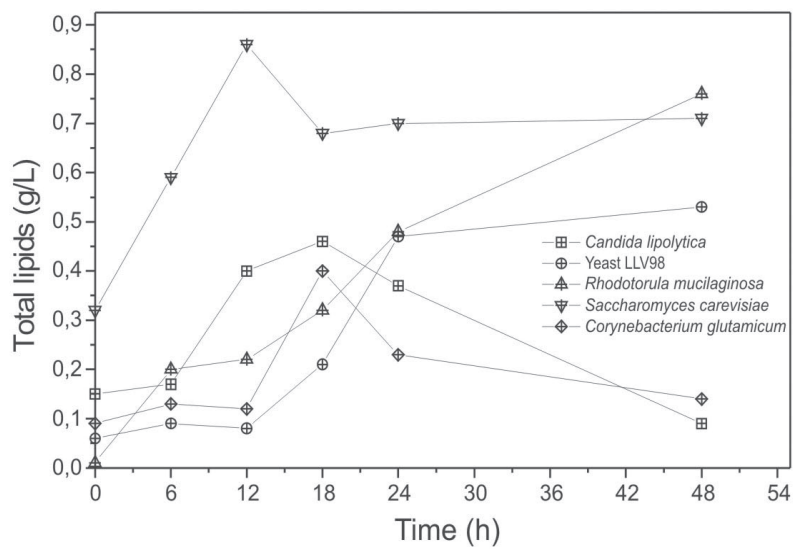

Figure 9. Total lipid productions $(\mathrm{g} / \mathrm{L})$ in $75 \%$ molasses and $25 \%$ vinasse after 48 hours

similar productions in all molasses and vinasse ratios (Figure 10). The $25 \%$ molasses and $75 \%$ vinasse was the worst culture medium for lipid productions. According to Ziino et al. (1999), the microbial composition is strongly affected by the cultivations conditions, medium composition being the most important. Generally, the poorer the carbon source the faster the growth rate and the lower the biomass lipid content, because the metabolic activities in such conditions are oriented preferably towards protein rather than lipid synthesis.

\section{References}

AGRAWAL, C.; PANDEY, G. Soil pollution by spent wash discharge: depletion of manganese. Journal of Environmental Biology, Lucknow, v.15, n.1, p.49-53, jan. 1994.

ALTAF, M. D.; NAVEENA, B. J.; VENKATESHWAR, M.; KUMAR, E. V.; REDDY, G. Single step fermentation of starch to $\mathrm{L}(+)$ lactic acid by Lactobacillus amylophilus GV6 in SSF using inexpensive nitrogen sources to replace peptone and yeast extract - optimization by RSM. Process Biochemistry, London, v.41, n.2, p.465472, 2005.

ANCIÃES, A. W. Avaliação tecnológica do álcool etílico. 3.ed. Brasília: Editorial do CNPq, 1981.

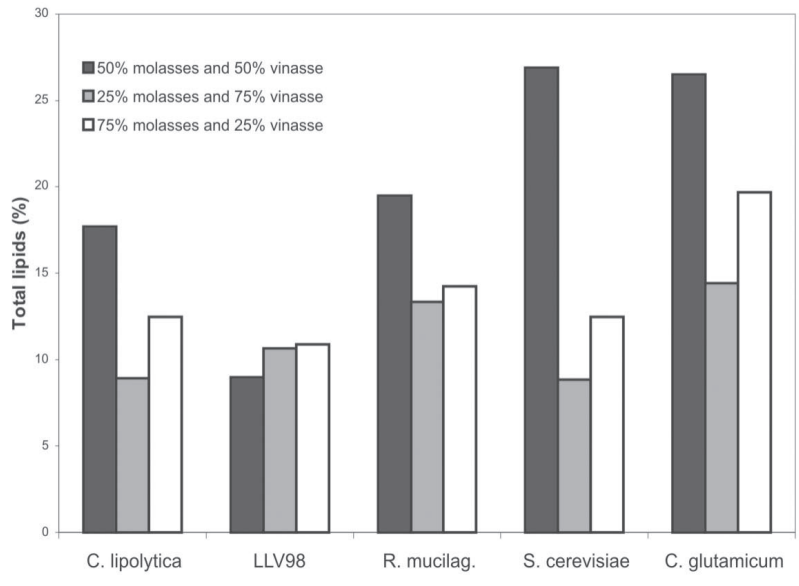

Figure 10. Total lipid productions $(\%)$ in the different molasses and vinasse ratio.

ANUPAMA, X.; RAVINDRA, P. Value-added food: single cell protein. Biotechnology Advances, New York, v.18, n.6, p.459-479, 2000.

ASSOCIATION OF OFFICIAL ANALYTICAL CHEMISTS. Official Methods of Analysis. 12.ed. Washington: AOAC, 1975.

ASSOCIATION OF OFFICIAL ANALYTICAL CHEMISTS. Official Methods of Analysis. 13.ed. Washington: AOAC, 1984.

ARNOLD, J. L.; KNAPP, J. S.; JOHNSON, C. L. The use of yeast to reduce the polluting potential of silage effluent. Wastes Research, v.34, n.15, p.36993708 , oct. 2000.

CORTEZ, L. A. B.; BROSSARD PÉREZ, L. E. Experiences On Vinasse Disposal Part III: Combustion of Vinasse-\# 6 Fuel Oil Emulsions. Brazilian Journal of Chemical Engineering, São Paulo, v.14, n.1, p.9-18, mar. 1997.

DIAZ, M. J.; EUGENIO, M. E.; JIMÉNEZ, L.; MADEJÓN, E.; CABRERA, F. Modelling vinasse/ cotton waste ratio incubation for optimum composting. Chemical Engineering Journal, Lausanne, v.93, n.3, p.233-240, jul. 2003.

DYAL, S. D.; NARINE, S. S. Implications in the use of Mortirella fungi in the industrial production of essential fatty acids. Food Research International, Barking, v.38, p.445-467, 2005. 
EMTIAZI, G.; ETEMADIFAR, Z.; TAVASSOLI, $\mathrm{M}$. A novel nitrogen-fixing cellulytic bacterium associated with root of corn is a candidate for production of single cell protein. Biomass and Bioenergy, Oxford, v.25, n.4, p.423-426, 2003.

FRINGS, C. S.; DUNN, R. T. A colorimetric method for determination of serum lipids based on the sulpho-phospho-vanilin reaction. American Journal of Clinical Pathology, Philadelphia, v.53, n.1, p.89-91, 1971.

KANNABIRAN, B.; PRAGASAN, A. Effect of destillery effluent on seed germination, seeding growth content of Vigna mugno Geobios, Lyon, v.20, p.108-112, 1993.

KUMAR, S.; VISWANATHAN, L. Production of biomass, carbon dioxide, volatile acids, during distillery waste treatment by bacterial strains. Enzyme Microbial Technology, New York, v.13, n.2, p.179187, feb. 1991.

MENEZES, T. J. B. Etanol: o combustível do Brasil. São Paulo: Agronômica Ceres, 1980.

MURPHY, D. Storage lipids bodies in plants and other organisms. Progress in Lipid Research, Oxford, v.29, p.299-234, 1991.

NAVARRO, A. R.; SEPÚLVEDA, M. C.; RUBIO, M. C. Bio-conversion of vinasse from alcoholic fermentation of sugar cane molasses. Waste Management, Oxford, v.20, p.581-585, 2000.

NELSON, N. A. A photometric adaptation of Somogy method for determination of glucose. Journal of Biological Chemists, Baltimore, v.153, n.1, p.375-380, 1944.

PARASKEVOPOULOU, A.; ATHANASIADIS, I.; KANELLAKI, M.; BEKATOROU, A.; BLEKAS, G.; KIOSSEOGLOU, V. Functional properties of single cell protein produced by Kefir microflora. Food Research International, Barking, v.36, p.431-438, 2003.
POLACK, J. A.; DAY, D. F.; CHO, Y. K. Gasohol from Sugarcane-Stillage Disposition: Report. Baton Rouge: Audubon Sugar Institute; Louisiana State University, 1981.p.47.

RATLEDGE, C. Microorganisms for lipids. In: Meesters PA, Huijberts GN. High-cell density cultivation of the lipid accumulating yeast Cryptococcus curvatus using glycerol as a carbon source. Applied Microbiology Biotechnology, Oxford, v.45, n.5, p.575-579, 1996.

\section{REUGER, M. J. S.; TAUK-TORNISIELO, S. M.}

Produção de biomassa por fungos filamentosos em meio de vinhaça de cana-de-açúcar suplementado com melaço. Arquivos de Biologia e Tecnologia, Curitiba, v.39, n.2, p.323-332, 1996.

RUPCIC, J.; BLAGOVIC, B.; MARIC, V. Cell lipids of the Candida lipolytica yeast grown on methanol. Journal of Chromatography A, New York, v.755, p.75-80, 1996.

SOMOGY, M. A. A new reagent for determination of sugar. Journal of Biology Chemistry, London, v.160, p.61-68, 1945.

WARD, O. P. Biotecnologia de la fermentacion. Zaragoza: Acríbia, 1991.

WALISZEWSKI, K.N.; ROMERO, A.; PARDIO, V.T. Use of cane condensed molasses in feeding broilers. Animal Feed Science Technology, Amsterdam, v. 67, p. 253-258, 1997.

ZHENG, S.; YANG, M.; YANG, Z.; YANG, Q. Biomass production from glutamate fermentation wastewater by co-culture of Candida halophila and Rhodotorula glutinis. Bioresource Technology, New York, v.96, n.13, p.1522-1524, 2005.

ZIINO, M. L. O.; CURTO, R. B.; SALVO, F.; SIGNORINO, D.; CHIOFALO, B.; GIUFFRIDA, D. Lipid composition of Geotricum candidum single cell protein grown in continuous submerged culture. Bioresource Technology, New York, v.67, p.7-11, 1999. 